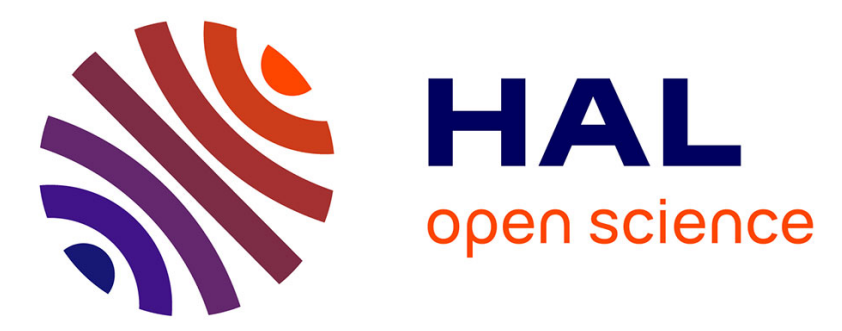

\title{
Dominica: transcrustal magmatic system and eruptive halogen budgets
}

Thiebaut d'Augustin, Hélène Balcone-Boissard, Georges Boudon, Caroline Martel, Etienne Deloule, Pierre Bürckel

\section{- To cite this version:}

Thiebaut d'Augustin, Hélène Balcone-Boissard, Georges Boudon, Caroline Martel, Etienne Deloule, et al. Dominica: transcrustal magmatic system and eruptive halogen budgets. EGU General Assembly 2020, May 2020, Online, France. 10.5194/egusphere-egu2020-13591 . hal-03554409

\author{
HAL Id: hal-03554409 \\ https://hal.science/hal-03554409
}

Submitted on 4 Feb 2022

HAL is a multi-disciplinary open access archive for the deposit and dissemination of scientific research documents, whether they are published or not. The documents may come from teaching and research institutions in France or abroad, or from public or private research centers.
L'archive ouverte pluridisciplinaire HAL, est destinée au dépôt et à la diffusion de documents scientifiques de niveau recherche, publiés ou non, émanant des établissements d'enseignement et de recherche français ou étrangers, des laboratoires publics ou privés. 


\section{EGU2020-13591}

https://doi.org/10.5194/egusphere-egu2020-13591

EGU General Assembly 2020

(c) Author(s) 2022. This work is distributed under

the Creative Commons Attribution 4.0 License.

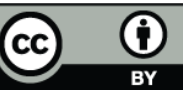

\section{Dominica: transcrustal magmatic system and eruptive halogen budgets}

Thiebaut d'Augustin ${ }^{1}$, Hélène Balcone-Boissard ${ }^{1}$, Georges Boudon ${ }^{2}$, Caroline Martel ${ }^{3}$, Etienne Deloule ${ }^{4}$, and Pierre Bürckel ${ }^{2}$

${ }^{1}$ Sorbonne Université, Institut des Sciences de la Terre de Paris (UMR 7193), France (thiebaut.daugustin@sorbonneuniversite.fr)

${ }^{2}$ Institut de Physique du Globe de Paris (IPGP), CNRS, Université de Paris

${ }^{3}$ Institut des Sciences de la Terre d'Orléans (ISTO), UMR 7327, Université d'Orléans-CNRS/INSU- BRGM

${ }^{4}$ CRPG, UMR 5873 CNRS-Université de Lorraine

Dominica island experienced the largest explosive eruptions (ignimbrites) of the Lesser Antilles arc. The recent revised chronostratigraphy of the Morne Trois Pitons - Micotrin eruptive activity evidenced a series of plinian eruptions that occurred between $18 \mathrm{ka}$ and $9 \mathrm{ka}$ BP. Here we focus on these recent eruptions in order to determine the magma storage conditions at depth and volatile degassing budget. Volatile concentrations $\left(\mathrm{H}_{2} \mathrm{O}, \mathrm{CO}_{2}\right)$ in melt inclusions indicate storage conditions of $200 \mathrm{MPa}\left(\sim 6-8 \mathrm{~km}\right.$ deep) and $860-880^{\circ} \mathrm{C}$ in agreement with experimental constraints from phaseequilibrium data. The magmas were thus stored shallower than those involved during the ignimbritic eruptions ( $16 \mathrm{~km}$ deep). Magma composition and halogen ratios suggest a common magma origin for all eruptions of Morne Trois Pitons Micotrin volcano in the last $60 \mathrm{kyrs}$. In addition, for the first time, a complete degassing budget including $\mathrm{H}_{2} \mathrm{O}, \mathrm{CO}_{2}, \mathrm{SO}_{2}, \mathrm{~F}, \mathrm{Cl}$, and $\mathrm{Br}$ has been established for all these explosive eruptions. The estimation of their eruptive fluxes towards the atmosphere supports the potential important role of halogen elements in the modification of atmosphere chemistry. $\mathrm{Br}$ degassing budget was the same order of magnitude as $\mathrm{S}$ whereas $\mathrm{F}$ and $\mathrm{Cl}$ budgets were 1 and 2 orders of magnitude higher than these two species. 